\title{
The karyotype of ukrainian mountain carpathian sheep breed
}

\section{Dzitsiuk V.' ${ }^{1}$ Typylo Ch. ${ }^{2}$, Kaplinskyi V. ${ }^{3}$}

1,2Institute of Animal Breeding and Genetics nd.a. M.V. Zubets of NAAS, Pohrebnyaka Str., 1, Chubinske, Boryspil region, Kyiv oblast, 08321, Ukraine, ${ }^{3}$ Institute of agriculture of Carpathian region of NAAS, Grushevskyi Str., 5, Obroshyne, Pustomytiv region, Lviv oblast, 81115, Ukraine; e-mail: 1, ${ }^{2}$ valentynadzitsiuk@gmail.com, ${ }^{3}$ inagrokarpat@gmail.com

The purpose. To study cytogenetic features of Ukrainian mountain carpathian sheep breed. Methods. Karyotype of 25 sheep of ukrainian mountain carpathian sheep breed of FF "Radvan-Nova" (Myloshevychi, Pustomytiv region, Lviv oblast) was probed by microscopic research of specimens of cells at the stage of metaphase of mitosis got from short-term culture of peripheral blood lymphocytes of animals. Preparation of specimens of chromosomes, analysis of morphology, grading and record-keeping aberrations of chromosomes was realized on the conventional procedures in laboratory of genetics of Institute of animal growing and genetics. Results. It was fixed that amount and structure of chromosomes of ukrainian mountain carpathian sheep breed matched to the norm, characteristic for that kind of animals. In structure of karyotype were acrocentric and metacentric chromosomes. From 722 analysed metaphase plates of sheep the share of aberrant cells made $19,22 \%$, of them aneuploid cells $-8,6$, polyploid $-0,86$, cells with breakages of chromosomes $-2,22$, frequency of paired fragments of chromosomes $-2,66$ and frequency of cells with asynchronous divergence of centromeric regions of chromosomes $-4,88 \%$. Conclusions. By number and structure of chromosomal complement ukrainian mountain carpathian sheep do not differ from other breeds of sheep. Of 27 pairs of chromosomes of karyotype of sheep chromosomes of I group of metacentric structure (which are bigger than other chromosomes) and gonosomes are identified with adequate accuracy. In connection with such feature it is possible to determine with what frequency these chromosomes participate in structural aberrations. Identification of separate chromosomes at routine color enables to use cytogenetic probes in practice of selection operation in sheep-breeding.

Key words: Ukrainian mountain carpathian sheep breed, chromosomes, metacentric and acrocentric structure of chromosomes, aberrations.

\section{https://doi.org/10.31073/agrovisnyk201901-05}

Animals of the Ukrainian South Carpathian sheep breed - wool-milk-meat production direction [1]. Their wool is a valuable raw material for both light industry and folk crafts. The local population in the Carpathians is traditionally engaged in the production of Hutsul carpets and bedsteads. From Ukrainian South Carpathian sheep after weaning lambs for two months of lactation receive $30-40 \mathrm{~kg}$ of commodity milk, in the best public utilities and the individual sector - 50 and more kilograms. Milk is used for the production of sheep cheese-brynza, which is in high demand among consumers. Indicators of meat productivity depend on the level of feeding: after feeding on natural mountain pastures, 8-9-month lambs have a live weight of $28-30 \mathrm{~kg}$, after intensive feeding of fattening - 36-38 kg. Slaughter output - 42-45\%, the output of pulp from the carcass - 70-75\%. After slaughter, the Ukrainian South Carpathian sheep get excellent quality sheep skin, which are used for the manufacture of fur-hood products [1].

The economic efficiency and profitability of the sheep breeding industry depends on the quality of the product, which is determined by its genetic potential. Therefore, in order to preserve and improve the productive and breeding qualities of animals, one should know the genetic structure of both a separate herd and a breed in general. However, such an important agricultural object as a sheep remains cytogenetically underestimated. The study of the karyotype of sheep has theoretical and practical significance, since in the chromosomes there are genes that determine the development of all the signs of the organism and chromosomal aberration of any type can be the reason for reducing their economic value and reproductive function [2]. 
Materials and methods of research. The object of the study was the number of sheep of the Ukrainian South Carpathian breed $(n=25)$, which are breeding in the FG "Radwan-Nova" with. Miloshovichi of the Pustomyty district of Lviv region. The cytogenetic study was carried out at the Genetics Laboratory of the Institute of Animal Breeding and Genetics named after MV Zubtsy (Chubinskoye village) using special techniques and related equipment. For the preparation of chromosomes, samples of culture of lymphocytes of peripheral blood of animals were used. Lymphocytes $(0,5 \mathrm{ml})$ were cultured for 72 hours in a medium RPMl-1640 $(2 \mathrm{ml})$ with the addition of inactivated serum of cattle $(0,5 \mathrm{ml})$, concanavalin $(0,1 \mathrm{ml})$ and gentamicin $(0,001 \mathrm{ml}-1 \mathrm{ml}$ medium). 2 hours before completion of cultivation, a solution of colchicine was added to the medium at a final concentration of 0,05 $\mu \mathrm{g} / \mathrm{ml}$. The hypotonic treatment was performed using a 0,56 M solution of KCL for 30 minutes, followed by fixation in a freshly prepared and cooled fixative - methyl alcohol and glacial acetic acid (3:1). The routine staining of chromosome preparations was performed by Gimza dye. Cell analysis under a microscope was conducted at an imestion increase of 1000 times and photographed. For analysis and photographing, metaphase plates were selected, in which the chromosomes were separated from each other. The obtained experimental data were processed by the methods of variation statistics.

Research results and their discussion. The cariological analysis carried out by us showed that the diploid set of chromosomes in the sheep of the Ukrainian South Carpathian breed, as shown by other authors who obtained their results at different times and with the help of cytogenetic technology of various levels $[3,4,5]$, consists of 54 chromosomes from them 26 pairs of autosomes and one pair of sex chromosomes (XX or XY) (Fig. 1).

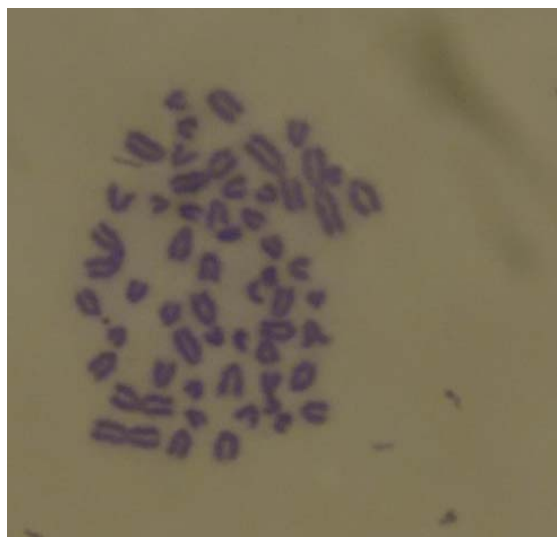

a)

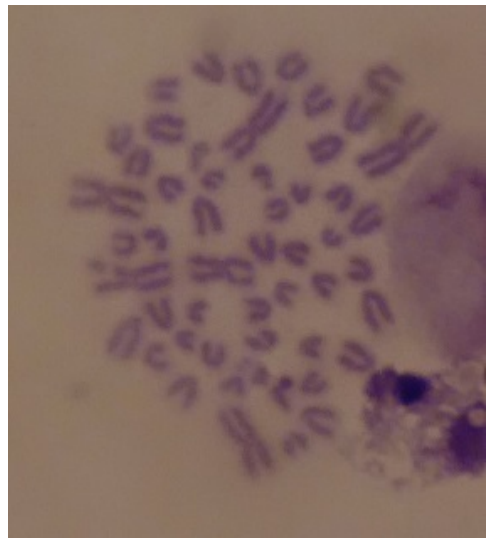

d)

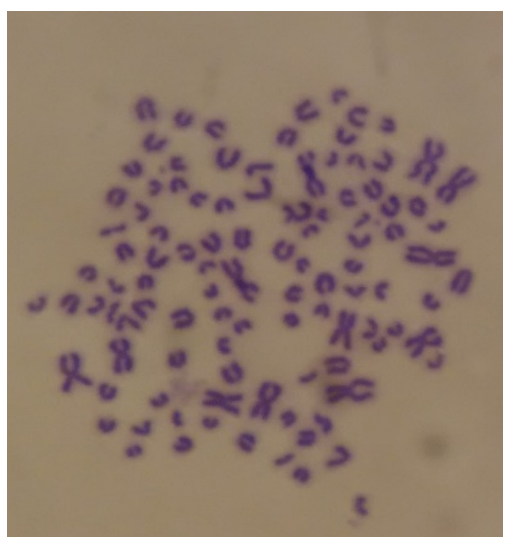

b)

c)

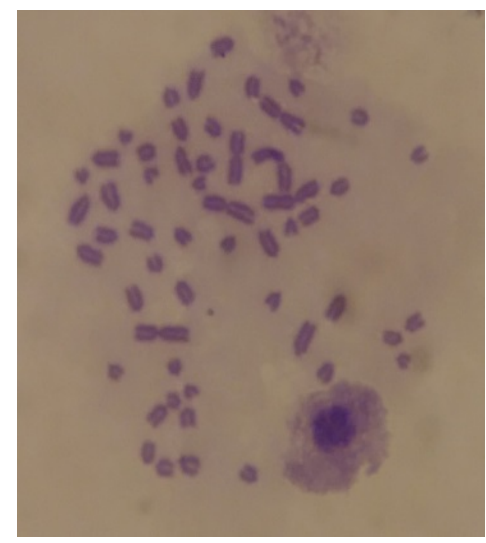

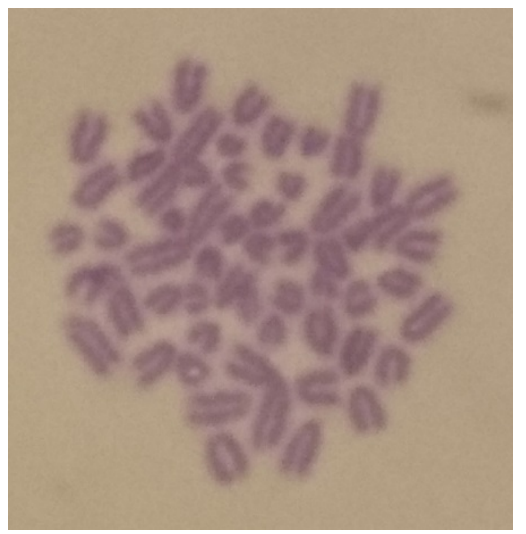

e)

Fig. 1. Preparations of chromosomes at the stage of metaphase: a) chromosomal set in normal; b) polyploid chromosome set; c) aneuploid chromosome set; d) a set with a chromosome with a rupture; e) set of chromosomes containing fragments of chromosomes. about. $\times 100$; OK. $\times 10$ 
The cariotype of the sheep of the Ukrainian South Carpathian breed consists of chromosomes, which, by morphological structure, can be divided into two groups: acrocentric and metacentric. In all studied samples, a series of autosomes is represented by three pairs of large metacentricians. The remaining 23 pairs form a series of gradually decreasing acrocentric chromosomes, most of which have a centrally located terminal. In sheep, acrocentric chromosomes do not have a significant difference in size, which makes it difficult to identify them without a differentiated color.

The group of metacentric chromosomes distinguishes the first pair, which is obviously larger than other chromosomal pairs. The difference in size between the second and third pairs is less obvious. The ratio of the short shoulder to the long first pair is $1: 1,3$. In the second and third pairs, this ratio is somewhat less. The most successful preparations of the chromosomes of the second and third pairs can be distinguished by the position of centromere, which is located somewhat more centrally in chromosomes of the third pair. The remaining autosomes form a series of gradual transitions from large acrocentrics to very small ones.

The individual characterization of the chromosomes of sheep under routine coloring is very complicated. Most clearly, one can identify the first pair of chromosomes and $\mathrm{X}$ chromosomes - the first pair is the largest metacentric, sex X chromosome - the largest acrocentric. The relative sizes of the Xchromosome vary considerably. Sometimes the predominance of the length of the $\mathrm{X}$ chromosome, as compared to the largest of the acrocentric autosomes, reached $15 \%$, in other chromosomal plates this prevalence was negligible. On separate preparations of the X-chromosome can be isolated on the longer elongated short shoulder, the frequency of such morphological features no more than $0,5 \%(2-3$ to 50 examined cells).

It is known from the literature that the $\mathrm{Y}$-chromosome is a small odd sub-metacentric chromosome present in male karyotypes and absent from females. We examined the karyotype only as a spin, and therefore, the $Y$ chromosome, of course, was not investigated.

Characteristic chromosomal polymorphism in the form of numerical variations in karyotype (aneuploidy and polyploidy), morphological aberrations, and associations of individual chromosomes is characteristic for sheep of the Ukrainian South Carpathian breed, as well as for other sheep of other breeds. The results of the analysis of chromosomal variability found that of the 722 analyzed metaphase plates of sheep of the Ukrainian mountain-Carpathian breed, the proportion of aberrant cells was $19.22 \%$, of which aneuploid cells $-8.6 \%$, polyploidy $-0.86 \%$, cells with chromosomal ruptures $-2,22 \%$, the frequency of pair chromosomal fragments was $2,66 \%$, and the frequency of cells with asynchronous divergence of centromeric regions of chromosomes (ARCSH) was 4,88\%.

The main proportion of aneuploids is represented by hypoplonids, the proportion of hyperplastics, as a rule, is negligible. The stability of the parameters of aneuploidy in sheep is confirmed by studies of many cytogenetics and can be considered a special feature. In sheep aneuploidy occurs more often than, for example, in cattle and it is formed by the small acrocenters.

The frequency of polyploid cells in sheep ranges from 0,53 to $1,36 \%$ and is lower than in pigs and higher than in cattle. The sheep are registered four-, six-, eight-, 16-podidity and more. The bulk of polyploids - tetraploids (64\%) and octaploids (21\%). The number of triploids and other polyploidy is insignificant and is approximately $15 \%$.

In the investigated sheep population, approximately $2 \%$ of the cells detected chromosomal ruptures. Structural changes in the chromosomes, in particular translocations, were not detected in animals of the studied population of the Ukrainian South Carpathian breed.

\section{Conclusions}

By the number and structure of the chromosome set of sheep of the Ukrainian South Carpathian breed do not differ from other breeds of sheep. Of the 27 pairs of chromosomes of the karyotype of sheep, the chromosomes of the first group, metacentric structure and larger than other chromosomes, size and sex chromosomes are identified with sufficient accuracy. In connection with this feature, it is possible to determine the frequency with which these chromosomes participate in structural aberrations, which allows the use of cytogenetic studies in the practice of breeding work in sheep breeding. 


\section{References}

1. lovenko V.M., Polska P.I., Antonets O.H. et al. (2006). Vivcharstvo Ukrainy [Sheepdog Ukraine]. Kyiv: Ahrarna nauka. 614 p. [in Ukrainian].

2. Sharipov I.K. (1991). Tsitogeneticheskiy test dlya otsenki genotipa ovets [Cytogenetic test to assess the genotype of sheep]. Novosti nauki Kazakhstana. Biotekhnologiya. Alma-Ata, P. 95 - 96. [in Russian].

3. Grafodatskiy A.S., Radzhabli S.I., Baranov O.K. (1988). Khromosomy sel'skokhozyaystvennykh i laboratornykh mlekopitayushchikh: atlas. [Chromosomes of farm and laboratory mammals: atlas]. Novosibirsk: Nauka. Sib. otdelenie, P. 127. [in Russian].

4. Meng L., Gongtao D., Kambol R. (2016). Chromosome karyotype analysis of cultivate somatic cells of Ganjia sheep. Science Letters. V. 10. Is. 1. P. $8-10$.

5. Tulegenov S. (2011). Kariotip ovets porody kazakhs'kiy arkharomerinos [The karyotype of sheep of the breed Kazakh araromerinos]. Nauchnyy zhurnal Kazakhskogo natsional'nogo agrarnogo universiteta. № 5. P. 30 - 33. [in Russian].

6. Vorontsov N.N., Korobitsyna K.V., Nadler Ch.F. (1972). Tsitogeneticheskaya differentsiatsiya granitsy vidov u nastoyashchikh baranov (Ovis S. Str.) [Cytogenetic differentiation of species in these sheep]. Palearktiki. Zool. zhurnal. T. 51. V. 8. P. 1109 - 1122. [in Russian].

7. Arslan A., Zima J. (2011). Banded karyotype of the Konya wild sheep (Ovis orientalis anatolica Valenciennes, 1856) from Turkey. Comp. Cytogenet. № 5. P. 81 - 89. Doi: 10.3897.compcytogen.v5i2.1151.

8. Di Meo G. P., Perucatti A., Floriot S. et al. (2005). Chromosome evolution and improved cytogenetic maps of the $\mathrm{Y}$ chromosome in cattle, zebu, river buffalo, sheep and goat. Chromosome Research. V. 13, Is. 4. P. $349-355$.

9. Słota E., Bugno M., Kozubska-Sobocińska A., Danielak-Czech B. (2007). Molekularne metody w analizach cytogenetycznych genomu zwierząt gospodarskich. Przegl. Hod. V. 6. P. $22-25$.

10. Dobigny G., Britton-Davidian J., Robinson T.J. (2017). Chromosomal polymorphism in mammals: An evolutionary perspective. Biological Reviews. V. 92. Is. 1. P. $1-22$. Doi: 10.1111.brv.12213. 